\title{
Study of Jaundice profile in Pregnancy in tertiary care centre in central India
}

\author{
Suri $\mathrm{AD}^{\mathbf{1}}$, Jain $\mathrm{RK}^{2}$, Jain $\mathrm{SC}^{3}$ \\ ${ }^{1}$ Dr Akash Deep Suri, Assistant Professor, Department of Medicine, Chirayu Medical College \& Hospital, Bhopal, India. ${ }^{2}$ Dr \\ R K Jain, Associate Professor, Dept of Medicine GMC Bhopal, ${ }^{3}$ Dr S C Jain, Ex Professor \& Head, Dept of Medicine \\ GMC Bhopal, India
}

Address for correspondence: Dr Akash Deep Suri, Email: akashdeepsuri@gmail.com

\begin{abstract}
Introduction: Pregnancy is complicated by various disorders including jaundice which is an important medical disorder seen more often in developing countries. Jaundice complicates pregnancy, whether of any cause. Jaundice in pregnancy carries a grave prognosis for both the fetus as well as mother. Therefore early detection of cause of jaundice improves the outcome of both. Methods: In present study 50 cases of clinical jaundice with pregnancy in any trimester were selected in the age group of 20 to 35 years over a period of one year. Results: Viral hepatitis was observed in 38 (76\%) cases, intrahepatic Cholestasis of pregnancy in $7(14 \%)$ cases, HELLP and hyperemesis gravidarum in $2(4 \%)$ cases each and a single case of drug induced jaundice. Maximum cases of jaundice in pregnancy were observed among the age group between $20-25$ years. Conclusion: Viral hepatitis was seen as the commonest cause of jaundice dominating in all the three trimesters alyhough third trimester having maximum 32 (64\%) cases. Therefore monitoring and early diagnosis of jaundice is necessary during pregnancy.
\end{abstract}

Key words: Jaundice, Pregnancy, Trimester, viral hepatitis

\section{Introduction}

Pregnancy is complicated by various disorders like hypertension, renal diseases, diabetes mellitus, cardiovascular disorders, hepatic disorders. ${ }^{1}$ Jaundice in pregnancy occur 1 in 1500 cases $^{2}$ and is an important medical disorder, seen more often in developing countries than in developed ones. Liver diseases in pregnancy includes liver disorders present at the time of conceptions like cirrhosis, chronic active hepatitis etc and those occurs coincidently but not exclusively in pregnancy likes viral hepatitis, drug induced hepatitis, Cholecystitis. It also includes Liver disease that occurs only in pregnancy like HELLP syndrome (Haemolysis, Elevated

Manuscript received: $15^{\text {th }}$ Oct 2013

Reviewed: $26^{\text {th }}$ Oct 2013

Author Corrected; $29^{\text {th }}$ Dec 2013

Accepted for Publication: 30 $0^{\text {th }}$ Dec 2013 lever enzymes \& Low platelets) $)^{3}$. Jaundice in pregnancy carries a grave prognosis for both the foetus and the mother and is responsible for $10 \%$ of maternal deaths. ${ }^{4}$ Early identification of cause of jaundice in pregnancy improves the outcome of both mother and foetus.

Developing countries like India are in epidemic area of viral hepatitis and there is delay in recognition of causes of jaundice during pregnancy and hence this study was undertaken to study the incidence of various causes of clinical jaundice in pregnancy.

\section{Materials and Methods}

Total 50 pregnancies with clinical jaundice in any trimester aged from 20 - 35 years were taken in this study 
from Gandhi Medical College, Bhopal Madhya Pradesh, India. The study was conducted over a period of one year. The cases of jaundice with chronic liver disease, haemolytic anaemia, gall stones, jaundice before the starts of pregnancy, cardiac disease and malignancy of liver are excluded from the study. The general, systemic and obstetric examinations along with complete history of

\section{Results}

Out of total 50 pregnancies with jaundice, 22 (44\%) patients were nulliparous \& $28(56 \%)$ were multiparous. The youngest patient was of 20 year old and oldest 34 years old. The age wise distribution is shown in Table-1. Maximum patients falls within the age group of 20 to 25 years i.e. 32 (64\%) and minimum in the age group of above 32 years i.e. 1 ( $2 \%$ ).

Table-1 Age wise distribution of Jaundice in Pregnancy

\begin{tabular}{|c|c|c|}
\hline Age Years & No of Pregnancy & Percentage \% \\
\hline $20-25$ & 32 & 64 \\
\hline $26-31$ & 17 & 2 \\
\hline$>32$ & 1 & 24 \\
\hline
\end{tabular}

According to the causes of clinical jaundice in pregnancy as shown in Table- 2, viral hepatitis is the commonest cause of jaundice in pregnancy seen in 38 cases out of $50(76 \%)$.

Next common cause includes Intrahepatic Cholestasis of pregnancy found in 7 (14\%) cases, followed by hyperemesis gravidarum and HELLP syndrome $2(4 \%)$ in cases of each. Only single case of drug induced hepatitis was observed.

Table-2 Table showing cases of Jaundice in Pregnancy according to etiology

\begin{tabular}{|c|c|c|c|}
\hline Sr. No & Diseases & Cases $\mathbf{( N = 5 0 )}$ & \% \\
\hline 1 & Viral Hepatitis & 38 & 76 \\
\hline 2 & Intrahepatic Cholestasis of Pregnancy & 2 & 4 \\
\hline 3 & HELLP Syndrome & 2 & 4 \\
\hline 4 & Hyperemesis Gravidarum & 1 & 2 \\
\hline 5 & Drug Induced hepatitis & 2 \\
\hline
\end{tabular}

Trimester wise distribution along with cause of jaundice in each trimester is shown in Table-3. There were maximum cases of viral hepatitis in $3^{\text {rd }}$ trimester of pregnancy i.e. 23 and 13 cases of viral hepatitis were noticed in $2^{\text {nd }}$ trimester. 
Table-3 Table showing trimester wise distribution of causes of Jaundice in pregnancy

\begin{tabular}{|c|c|c|c|}
\hline Causes & $\mathbf{1}^{\text {st }}$ Trimester & $\mathbf{2}^{\text {nd }}$ Trimester & $\mathbf{3}^{\text {rd }}$ Trimester \\
\hline Viral Hepatitis & 2 & 13 & 23 \\
\hline Intrahepatic Cholestasis of Pregnancy & - & - & 7 \\
\hline HELLP Syndrome & - & - & - \\
\hline Hyperemesis Gravidarum & 2 & - & - \\
\hline Drug Induced & - & 1 & 32 \\
\hline Total (out of 50) & 4 & 14 & \\
\hline
\end{tabular}

\section{Discussion}

Jaundice complicates pregnancy carries a grave prognosis for both the fetus and the mother and is responsible for $10 \%$ of maternal deaths ${ }^{4}$.

Management of pregnant women with jaundice assumes importance because two lives are at stake. It depends on identification of underlying etiology of jaundice in pregnancy.

Early identification of cause of jaundice in pregnancy improves the outcome of both mother and foetus.

Viral hepatitis is most common cause of jaundice in pregnancy.

In present study cases of viral hepatitis are observed with a highest percentage of $76 \%$ (38 cases) amongst 50 pregnancies with clinical jaundice. Viral

hepatitis is also most common cause of jaundice in each trimester of pregnancy. The similar finding was noted by Nagaria and Agarwal ${ }^{4}$, Mitra et $\mathrm{al}^{5}$, Wolf $\mathrm{JL}^{6}$, Sookoian $\mathrm{S}^{7}$, Jan et $\mathrm{al}^{8}$.

Shukla et $\mathrm{al}^{9}$ found that the incidence of viral hepatitis causing jaundice was $57 \%$ and Lahiri $\mathrm{BC}^{10}$ reported $90 \%$ cases of viral hepatitis amongst the study conducted on 290 patients, while Ching et $\mathrm{al}^{11}$ reported half of patient out of 48 were of viral hepatitis in pregnancy.
Intrahepatic cholestasis was observed as second commonest cause of jaundice in pregnancy in 7 cases (14\%). Our findings are similar to the findings reported by Dhawan and Sainani ${ }^{2}$. Ching et $\mathrm{al}^{11}$ reported 5 out of 48 cases of intrahepatic cholestasis in pregnancy.

All the cases of intrahepatic cholestasis of pregnancy were observed in the third trimester of pregnancy simillar to the study by Ch'gh et $\mathrm{al}^{12}$ in South Wales.

Two cases of HELLP syndrome were reported in present study both in $3^{\text {rd }}$ trimester. Our observations are supported by the observations by $\mathrm{Ch}^{\prime}$ gh et $\mathrm{al}^{12}$ who also found HELLP cases in the third trimester of pregnancy. Ching et $\mathrm{al}^{8}$ reported 2 cases out of 48 of HELLP syndrome in pregnancy.

Viral hepatitis remains the commonest cause of jaundice in pregnancy in all three trimesters. Our observations are supported by Abell and Riely ${ }^{13}$ who observed that viral hepatitis was the leading cause of the jaundice in all the three trimesters.

In present study we have found $2(5.26 \%)$ cases in $1^{\text {st }}$ trimester, $13(34.21 \%)$ in $2^{\text {nd }}$ trimester and $23(60.52 \%)$ in $3^{\text {rd }}$ trimester out of 38 .

That means viral hepatitis was most common in $3^{\text {rd }}$ trimester of pregnancy. Similar finding was noted by, Jaiswal et al ${ }^{14}(72 \%)$, Singh S et $a^{15}(72 \%)$ \& Shukla et 
$\mathrm{al}^{9}(75 \%)$ of cases in the third trimester of pregnancy which was slightly higher than our study. Two cases of hyperemesis gravidarum were observed during first trimester of pregnanacy. Ch'gh et $\mathrm{al}^{12}$ reported hyperemisis gravidarum in approximately in $9^{\text {th }}$ week of pregnancy.

\section{Conclusion}

Viral hepatitis is the commonest cause of jaundice in pregnancy and is also common in all the three trimesters. Both mother and child are affected by the jaundice. Therefore early diagnosis will help in the better management of jaundice preventing morbidity and mortality.

Funding: Nil

Conflict of interest: Nil

Permission from IRB: Yes

\section{References}

1. Ferris TF. Medical disorder during pregnancy. Harrison's principle of Internal Medicine. 13 ${ }^{\mathrm{TH}}$ Ed (1): 18-23. USA. McGraw-Hill Companies. 1994.

2. Dhawan PS, Sainani GS. Diagnosis of liver disorder in pregnancy. Am J Obstetrics \& Gynaecology. 1996; 23: 609-13.

3. Kaczynski K, Kamili S. Global epidemiology and Medical aspect of hepatitis E. Forum (Geneva). 2001; (2):166-179.

4. Nagaria T, Agarwal S. Fetomaternal outcome in jaundice during pregnancy. J Obstet Gynecol India. 2005;55:424-427

5. Mitra AK, Patki PS, Mitra SK. Liver disorders during pregnancy and their management. The Antiseptic. 2008 ; 105 (4): 193-196.

6. Wolf JL. Liver disease in pregnancy. Med Clinics of North Am. 1996; 80:1167-1187.

7. Sookoian S. Liver disease during pregnancy: acute viral hepatitis. Annals of Hepatology. 2006; 5(3): 231-236.

8. Jan Y, Bilques S, Najmi AM, Qureshi MA, Khan SS, Rafiq M, Ashfaq A. Viral Hepatitis during Pregnancy: A Study of Its Socio- Clinical Profile in A Tertiary Care Hospital. J Dental and Med Sci. 2012 Dec; 3(2):18-22.

9. Shukla S, Mehta G, Jais M, Singh A. A Prospective Study on Acute Viral Hepatitis in Pregnancy; Seroprevalence and Fetomaternal Outcome of 100 cases. J Biosci Tech. 2011; 2 (3): 279-286.

10. Lahiri BC. Jaundice in pregnancy. J Obstet Gynaecol India. 1976; 26: 363-67,

11. Ching LY, Barge N, Dalal AR. Study of jaundice in a tertiary care institution in India. Bombay Hospital J. 2011; 53: $181-183$.

12. Ch'ng CL, Morgan M, Hainsworth I, Kingham JGC. Prospective study of liver dysfunction in pregnancy in Southwest Wales. Gut. 2002; 51: 876-880. 
13. Abell TL, Riely CA. Hyperemesis gravidarum. Gastroentrol Clinic North Am. 1992; 21: 835.

14. Jaiswal SP, Jain AK, Naik G, Soni N, Chitnis DS. Viral hepatitis during pregnancy. Int J Gynaecol Obstet. 2001;72: 103-8.

15. Singh S, Mohanty A, Joshi YK, Deka D, Mohanty S, Panda SK. Mother-to-child transmission of hepatitis E virus infection. Indian J Pediatr. 2003 Jan; 70(1): 37-39.

\section{How to cite this article?}

Suri AD, Jain RK, Jain SC. Study of Jaundice profile in Pregnancy in tertiary care centre in central India. Int J Med Res Rev 2014;2(1):3-7.10.17511/ijmrr.2014.i01.02 